\title{
Syncope in Children: Is Rhythm Holter Monitoring Necessary?
}

\section{Çocuklarda Senkop: Ritim Holter Monitörizasyonu Gerekli mi?}

\author{
Fahrettin Uysal, Özlem Mehtap Bostan, Fatma Çetinkaya*, Tuba Deniz*, Ergün Çil \\ Uludağ University Faculty of Medicine, Department of Pediatric, Division of Pediatric Cardiology, Bursa, Turkey \\ *Uludağ University Faculty of Medicine, Department of Pediatrics, Bursa, Turkey
}

\section{Keywords}

Syncope, children, Holter monitoring, concealed long QT syndrome

\section{Anahtar kelimeler \\ Senkop, çocuk, Holter monitörizasyonu, gizli uzun QT sendromu}

Received/Geliş Tarihi : 11.02.2015

Accepted/Kabul Tarihi : 02.10.2015

DOI: $10.4274 /$ jcp.32932

Address for Correspondence/Yazışma Adresi: Fahrettin Uysal, MD, Uludağ University Faculty of Medicine, Department of Pediatric, Division of Children's Cardiology,

Bursa, Turkey

Phone: +902242950454

E-mail: fahrettin_uysal@mynet.com

\footnotetext{
(C) The Journal of Current Pediatrics, Published by Galenos Publishing House.

This article is distributed under the terms of the

"Creative Commons Attribution NonCommercial 4.0

International Licence (CC BY-NC 4.0)",
}

\begin{abstract}
Introduction: Holter monitoring (HM) is usually used in patients with syncope when etiology cannot be explained with history, physical examination and electrocardiography (ECG). In this study the objective was to evaluate the diagnostic value of HM in children with syncope.

Materials and Methods: Databases were collected retrospectively by analyzing the HM results of 3.122 pediatric patients between 2010-2014. Gender, age at diagnosis, detailed clinical history, physical examination, 12-lead electrocardiographic and echocardiographic results were noted using standardized form.

Results: The study included 323 patients with syncope with a mean age of 13.21 \pm 3.67 . There were 199 female and 124 male patients in this study. Among all patients $284(87.9 \%)$ had normal HM results, while $11(3.4 \%)$ patients had abnormal Holter studies that consider to explain as syncope. Three of 11 patients with abnormal Holter results diagnosed through ECG before HM, hence, the diagnostic value of HM was calculated as $2.4 \%$. In contrast, diagnostic value of $\mathrm{HM}$ in patients with positive family history was found to be $16.6 \%$. In this study, 7 patients were considered to have long QT syndrome according to their HM findings.

Conclusions: Detailed clinical history has a great value in children with syncope. As a result, HM has low diagnostic value if the patients are not in high risk group. However, HM was considered to be important because of concealed long QT syndrome especially if the patient had positive family history and exercise related syncope.

$\ddot{\mathbf{O} z}$

Giriş: Senkop geçiren hastalarda anamnez, fizik muayene ve elektrokardiyografi (EKG) ile etiyoloji açıklanamıyorsa genellikle Holter monitörizasyonu (HM) yapılır. Bu çalışmada senkoplu çocuklarda HM'nin tanısal değerinin belirlenmesi amaçlanmıştır.

Gereç ve Yöntem: Bu çalışmada 2010-2014 yılları arasında hastalara uygulanan toplam 3,122 HM retrospektif olarak incelendi. Hastaların cinsiyet, tanı yaşı, ayrıntılı anamnez, fizik muayene, 12-derivasyon EKG ve ekokardiyografik sonuçları standart form kullanılarak kayıt edildi.

Bulgular: Çalışmaya yaş ortalaması 13,21 33,67 olan 323 hasta dahil edildi. Hastaların 199'u kız, 124'ü erkek idi. Tüm hastaların 284'ünde $(\% 87,9)$ Holter sonuçları normal saptanırken 11 hastada $(\% 3,4)$ senkopu açıklayan anormal Holter sonuçları tespit edildi. Anormal Holter sonuçları olan 11 hastanın üçünde HM öncesinde uygulanan EKG ile tanı konduğu için HM'nin tanısal değeri \% 2,4 olarak hesaplandı. Aile öyküsü pozitif olan çocuklarda ise HM'nin tanısal değeri \%16,6 olarak bulundu. Çalışmada EKG'si normal olan yedi hastada ise HM sonucu ile uzun QT sendromu düşünüldü.
\end{abstract}


Sonuç: Senkop geçiren çocuklarda ayrıntılı anamnez çok değerlidir. Sonuç olarak HM'nin, yüksek risk grubu olmayan hastalarda tanısal değeri düşüktür. Ancak özellikle pozitif aile öyküsü olanlarda ve eforla ilişkili senkopu olan çocuklarda gizli uzun QT sendromu açısından HM'nin değerli olabileceği düşünüldü.

\section{Introduction}

Syncope is a common symptom among children that extensively disturbs families and often requires cardiovascular evaluation. It also accounts 1-3\% of the emergency service admissions and $6 \%$ of the hospitalizations $(1,2)$. Incidence of syncope requiring medical care was reported to be 126 of 100.000 children (3). In a study, it was shown that $11 \%$ of the patients experienced at least one syncope episode during the 18 years of follow-up period (4). Rate of recurrence over 5 years is between $33 \%$ and $51 \%$ (5). Although the most common causes of syncope in children are not important, cardiac causes are associated with considerable morbidity and mortality. Therefore, cardiac evaluation is necessary for all patients. Despite detailed history and physical examination is mostly adequate for identifying the syncope etiology; various tests according to the initial clinical evaluation have been recommended. Holter monitoring (HM) is usually ordered by clinicians when syncope etiology cannot be explained with history, physical examination and electrocardiography (ECG) (6). In various studies; diagnostic value of HM in adult patients with syncope was $4-8.6 \%(7,8)$. But studies related with this issue in children are rare. In this study, diagnostic value of the 24-hour rhythm HM admitted to the outpatient clinic of the pediatric cardiology between January 2010-September 2014 in patients with syncope was evaluated.

\section{Materials and Methods}

\section{Patients Characteristics}

From January 2010-September 2014, children with syncope ranging in age from 1 year to 18 years were evaluated at the Uludag University Faculty of Medicine, Department of Pediatric, Division of Pediatric Cardiology, a tertiary medical center in Turkey. Databases were collected retrospectively by analyzing the HM data of pediatric patients and the following data were retrieved from the clinical records; gender, age at initial syncope, detailed clinical history, physical examination, 12-lead ECG and echocardiography. All Holter studies performed in patients due to syncope were reviewed for significant arrhythmias as the cause of syncope. The patient was considered high risk if there was a family history of sudden death under $<40$ years old and if there was an exercise related syncope.

\section{Holter Monitoring}

$\mathrm{HM}$ of the patients were performed for 24 hours by using North East ${ }^{\circledR}$ monitoring device with 3 channels. Results were classified as follows:

1. Normal Holter results; completely normal or presence of clinically insignificant arrhythmia, i.e.; rare atrial (AES) or ventricular extrasystole (VES).

2. Abnormal Holter results; without explanation for syncope, i.e.; branch block, $2^{\circ}$ atrioventricular (AV) block Mobitz type-1, frequent VES or AES, nonsustained ventricular tachycardia (VT) $(<30 \mathrm{sec})$.

3. Abnormal Holter results; diagnostic for syncope, i.e.; $2^{\circ} \mathrm{AV}$ block Mobitz type- $2,3^{\circ} \mathrm{AV}$ block, $\geq 3 \mathrm{sec}$ of sinus pause, $>30 \mathrm{sec}$ of supra-VT, $<35 / \mathrm{min}$ of sinus bradycardia, sustained VT ( $\geq 30 \mathrm{sec}$ ), long QT syndrome.

QTc values in the HM were calculated manually using Bazett formula during tachycardia and bradycardia. Patients with long QT values were additionally evaluated with exercise test and genetic test.

\section{Statistical Evaluation}

Statistical analyses were performed by using SPSS 20.0 package program compatible with Windows. Normal distribution consistency of the data was analyzed with Kolmogorov-Smirnov test during statistical analysis. Variables with normal distribution properties were presented as mean \pm standard deviation. Nominal values were presented as percentages. Relations between variables were evaluated with chisquare correlation analysis. T-test and Mann-Whitney $\mathrm{U}$ test were used for numerical independent variables with and without normal distribution, respectively. Significance was determined as $p<0.05 p$ values in this study. 


\section{Results}

A total of 3.122 HM performed during study period were evaluated; among them; 323 patients $(10.3 \%)$ with Holter examination due to syncope were enrolled in this study. Their mean age was $13.21 \pm 3.67$. There were 199 female and 124 male patients. Among of all patients, 146 of them had 1, 95 of them had 2 and 82 of them had 3 or more syncope episode. There were 42 patients with history of sudden death $<40$ years old in first-degree relatives. Demographic and clinical characteristics of the patients are shown in Table 1.

The most frequent cause of structural heart disease was mitral valve prolapses (13 patients). Furthermore there was 1 patient with atrial septal defect, one patient that was operated for tetralogy of Fallot and two patients that were operated for ventricular septal defect while the remaining 306 patients had normal echocardiographic examination.

Of the 323 enrolled patients during the study period, 284 (87.9\%) had normal HM results. Twentyeight patients $(8.6 \%)$ had abnormal HM results, but unlikely to explain syncope while there were 11 (3.4\%) abnormal Holter studies considered to explain syncope. Table 2 summarizes the HM results of the cases. All of seven patients considered as long QT syndrome with $\mathrm{HM}$, had positive family history and their QTc values were normal in basal ECG. There were two patients

\begin{tabular}{ll}
\hline $\begin{array}{l}\text { Table 1. Demographic and clinical characteristics of } \\
\text { study population }\end{array}$ & $\mathrm{n}(\%)$ \\
\hline Variables & 323 \\
\hline Total number of patients & $13.21 \pm 3.67$ \\
Age (years) & $199(61.6)$ \\
Females & \\
Frequency of syncope & $146(45.2)$ \\
$\quad$ First episode & $95(29.4)$ \\
2 episode & $82(25.3)$ \\
$\geq 3$ episode & $42(13)$ \\
Family history of sudden death & $35(10.8)$ \\
Exercise related syncope & $17(5.2)$ \\
Structural heart disease & $11(3.4)$ \\
$\quad$ Mitral valve prolapses & $2(0.6)$ \\
Operated for ventricular septal defect & $2(0.6)$ \\
Operated for fallot tetralogy & $1(0.3)$ \\
$\quad$ Atrial septal defect &
\end{tabular}

with congenital complete AV block and syncope. One of two patients considered as sinus node dysfunction according to the Holter examination had nodal rhythm; whereas other patient had sinus bradycardia in ECG and both of these patients underwent transvenous pacemaker implantation.

Thirty of the 284 patients with normal Holter results had positive family history and all of them had normal physical and ECG examination findings. Diagnostic value of HM was significantly higher among patients with family history of sudden death and syncope associated with exercise. However it was found that the syncope frequency did not alter the diagnostic value of HM. Table 3 demonstrates diagnostic yields of HM results according to different parameters.

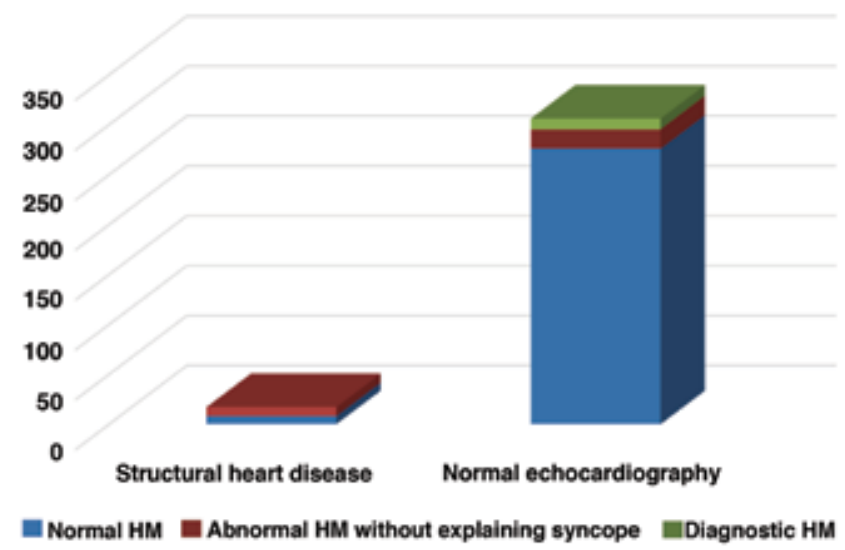

Figure 1. Holter monitoring results of patients with or without structural heart disease HM: Holter monitoring

Table 2. Results of Holter monitoring in children with syncope

\begin{tabular}{ll}
\hline Holter monitoring results & $\mathrm{n}(\%)$ \\
\hline Normal & $284(87.9)$ \\
Abnormal without explaining syncope & $28(8.6)$ \\
$\quad$ Frequent atrial extrasystole & $15(4.6)$ \\
Ventricular extrasystole (>60/hour) & $8(2.4)$ \\
$2^{0}$ AV block Mobitz type-1 & $4(1.2)$ \\
Non-sustained VT & $1(0.3)$ \\
Abnormal explaining syncope & $11(3.4)$ \\
Long QT syndrome & $7(2.1)$ \\
Complete AV block & $2(0.6)$ \\
Sick sinus syndrome & $2(0.6)$ \\
\hline VT: Ventricular tachycardia, AV: Atrioventricular & \\
\hline
\end{tabular}


Abnormal HM findings that were not diagnostic for syncope were found in nine patients with structural heart disease while the remaining eight patients with structural heart disease had normal Holter results (Figure 1). Thus, HM results revealed no arrhythmias associated with syncope in patients with underlying heart disease.

\section{Discussion}

Although evaluation of syncope is often performed with several tests; $25-50 \%$ of the patients cannot be diagnosed (9-11). Various guidelines have been published for diagnostic evaluation of patients. Detailed history, physical examination and ECG are essential for diagnosing in children with syncope and play an important role in determination of initial evaluation (12). Exercise test, cardiac imaging and HM are recommended for patients with syncope; especially if it is associated with exercise (13).

Prevalence of syncope related with arrhythmia during HM was reported as $2 \%$ in one study (14). Another study performed by Linzer et al. (6) it was shown that $4 \%$ of the patients had arrhythmia related with syncope during 12-hour HM. In patients with high risk and structural heart disease, relation between severe arrhythmia and syncope was shown in $12 \%$ of the patients (8). Therefore, it could be argued that diagnostic value of the HM in patients with syncope is low when patients were not selected appropriately

Table 3. Diagnostic yield of Holter monitoring results according to different parameters

\begin{tabular}{|c|c|c|c|c|}
\hline & & $\begin{array}{l}\text { Diagnostic } \\
\mathrm{HM} \\
(\mathrm{n}=11)\end{array}$ & $\begin{array}{l}\text { Non- } \\
\text { diagnostic } \\
\text { HM } \\
(n=312)\end{array}$ & $\mathrm{p}$ \\
\hline \multirow{2}{*}{$\begin{array}{l}\text { Family } \\
\text { history } \\
\text { of } \\
\text { sudden } \\
\text { death }\end{array}$} & Present & $\begin{array}{l}7 / 42 \\
(16.6 \%)\end{array}$ & $\begin{array}{l}35 / 42 \\
(83.3 \%)\end{array}$ & \multirow[b]{2}{*}{$<0.0001$} \\
\hline & Absent & $\begin{array}{l}4 / 281 \\
(1.4 \%)\end{array}$ & $\begin{array}{l}277 / 281 \\
(98.5 \%)\end{array}$ & \\
\hline \multirow{2}{*}{$\begin{array}{l}\text { Exercise } \\
\text { related } \\
\text { syncope }\end{array}$} & Present & $\begin{array}{l}5 / 35 \\
(14.2 \%)\end{array}$ & $\begin{array}{l}30 / 35 \\
(85.7 \%)\end{array}$ & \multirow{2}{*}{0.003} \\
\hline & Absent & $\begin{array}{l}6 / 288 \\
(2 \%)\end{array}$ & $\begin{array}{l}282 / 288 \\
(97.9 \%)\end{array}$ & \\
\hline \multicolumn{2}{|c|}{ Syncope frequency } & $2.0 \pm 0.8$ & $1.9 \pm 0.7$ & 0.643 \\
\hline \multicolumn{2}{|l|}{ Age } & $12.31 \pm 2.43$ & $13.54 \pm 2.84$ & 0.157 \\
\hline \multicolumn{4}{|c|}{ HM: Holter monitoring } & \\
\hline
\end{tabular}

(15). In our study, 11 of the patients had arrhythmia associated with syncope; however; 3 of these patients had already been diagnosed with previous ECG. Therefore, overall diagnostic value of the Holter examination was low as $2.4 \%(8 / 323)$. In contrast, 7 of $42(16.6 \%)$ patients especially considered as high risk group in terms of positive family history had diagnostic Holter results. Similarly, 5 of the 35 patients with syncope associated with exercise had diagnostic Holter results (14.2\%). Similar to the previous studies, it was concluded that HM is more valuable in high-risk patients. On the contrary, however; HM was not found to be useful in patients with structural heart disease in our study.

There was no significant association between syncope frequency and diagnostic value of HM and also the age of patients did not affect the diagnostic yield of HM.

The most frequent group diagnosed as a result of abnormal HM associated with syncope was long QT syndrome in our study population. It was known that $27 \%$ of the patients with long QT syndrome had normal ECG although they were genetically positive for disease (16). This patient group named as concealed long QT syndrome apparently couldn't be identified with basal ECG examination. Moreover it was also shown that many clinicians did not calculate QT values on ECG accurately (17). In our study, seven patients considered as long QT syndrome according to HM findings although the ECG revealed normal QT measurements and all of these patients had positive family history. Therefore, it was emphasized that HM could be used for concealed long QT syndrome especially if the syncope was associated with positive family history and exercise related syncope even with normal basal ECG findings.

All of seven patients were genetically tested for long QT syndrome type-1, type-2 and type-3; and 1 of them was diagnosed with long QT syndrome type1. Remaining patients were scheduled for genetically tests of other types of long QT syndrome.

\section{Conclusion}

Detailed history, physical examination and ECG are invaluable in children with syncope. HM was established to be unnecessary in patients without high risk and its diagnostic value was considered as low 
among these patients. It was found that HM could be useful in high risk children especially to detect concealed long QT syndrome.

\section{Ethics}

Peer-review: Externally peer-reviewed.

\section{Authors Contributions}

Surgical and Medical Practices: Fahrettin Uysal, Özlem Mehtap Bostan, Concept: Fahrettin Uysal, Ergün Çil, Design: Özlem Mehtap Bostan, Ergün Çil, Data Collection or Processing: Fatma Çetinkaya, Tuba Deniz, Literature Search: Fatma Çetinkaya, Tuba Deniz, Writing: Fahrettin Uysal.

Conflict of Interest: No conflict of interest was declared by the authors.

Financial Disclosure: The authors declared that this study received no financial support.

\section{References}

1. Brignole M, Menozzi C, Moya A, et al. Mechanism of syncope in patients with bundle branch block and negative electrophysiological test. Circulation 2001;104:2045-50.

2. Farwell D, Sulke N. How do we diagnose syncope? J Cardiovasc Electrophysiol 2002;13:S9-13.

3. Kapoor WN. Syncope. N Engl J Med 2000;343:1856-62.

4. Soteriades ES, Evans JC, Larson MG, et al. Incidence and prognosis of syncope. N Engl J Med 2002;347:878-85.

5. Driscoll DJ, Jacobsen SJ, Porter CJ, Wollan PC. Syncope in children and adolescents. J Am Coll Cardiol 1997;29:1039-45.
6. Linzer M, Yang EH, Estes NA, Wang P, Vorperian VR, Kapoor WN. Diagnosing syncope. Part 2: Unexplained syncope. Clinical Efficacy Assessment Project of the American College of Physicians. Ann Intern Med 1997;127:76-86.

7. Kuhne M, Schaer B, Moulay N, Sticherling C, Osswald S. Holter monitoring for syncope: diagnostic yield in different patient groups and impact on device implantation. QJM 2007;100:771-7.

8. Sarasin FP, Carballo D, Slama S, Louis-Simonet M. Usefulness of 24-h Holter monitoring in patients with unexplained syncope and a high likelihood of arrhythmias. Int J Cardiol 2005;101:2037.

9. Katritsis DG, Camm AJ. Nonsustained ventricular tachycardia: where do we stand? Eur Heart J 2004;25:1093-9.

10. Dolz Aspas R, Samperiz Legarre P, Calvo Begueria E, et al. [Syncope: many studies and few diagnoses?]. Rev Clin Esp 2004;204:9-13.

11. Manolis AS, Linzer M, Salem D, Estes NA, 3rd. Syncope: current diagnostic evaluation and management. Ann Intern Med 1990;112:850-63.

12. Sheldon R, Rose $S$, Ritchie D, et al. Historical criteria that distinguish syncope from seizures. J Am Coll Cardiol 2002;40:142-8.

13. Sarasin FP, Junod AF, Carballo D, Slama S, Unger PF, LouisSimonet M. Role of echocardiography in the evaluation of syncope: a prospective study. Heart 2002;88:363-7.

14. Gibson TC, Heitzman MR. Diagnostic efficacy of 24-hour electrocardiographic monitoring for syncope. Am J Cardiol 1984;53:1013-7.

15. Wohrle J, Kochs M. Syncope in the elderly. Z Gerontol Geriatr 2003;36:2-9.

16. Tester DJ, Will ML, Haglund CM, Ackerman MJ. Effect of clinical phenotype on yield of long QT syndrome genetic testing. J Am Coll Cardiol 2006;47:764-8.

17. Viskin S, Rosovski U, Sands AJ, et al. Inaccurate electrocardiographic interpretation of long QT: the majority of physicians cannot recognize a long QT when they see one. Heart Rhythm 2005;2:569-74. 